\title{
SPORTINIŲ ŽAIDIMŲ IR CIKLINIŲ SPORTO ŠAKŲ PRATYBŲ POVEIKIS 11-14 METU BERNIUKŲ FUNKCINIAM PARENGTUMUI
}

\author{
Arūnas Emeljanovas, Jonas Poderys \\ Lietuvos kūno kultūros akademija, Kaunas, Lietuva
}

\begin{abstract}
Arūnas Emeljanovas. Biomedicinos mokslų daktaras. Lietuvos kūno kultūros akademijos Kūno kultūros katedros lektorius. Mokslinių tyrimu kryptys: skirtingų fizinių krūvių poveikis paauglių organizmui; mokinių fizinio aktyvumo problematika.
\end{abstract}

\section{SANTRAUKA}

11-14 metu amžiaus tarpsniu organizmas labai jautrus išorès poveikiams, todèl šio amžiaus sportuojančiu berniuku tyrimai yra reikalingi ir gali atskleisti sudètinga igimtu bei igyjamu (endogeniniu ir egzogeniniu) veiksniu ryš̉. Tyrimo tikslas — palyginti iš dalies reglamentuoto fizinio krūvio, kuris būdingas sportiniu žaidimu veiklai, ir griežtai reglamentuoto fizinio krūvio, vyraujančio cikliniu sporto šaku pratybose, poveiki vaiku funkciniam parengtumui.

Tyriamuju kontingenta sudarè 257 11-14 m. amžiaus berniukai. Visi tiriamieji suskirstyti i tris grupes: nesportuojančius, kultivuojančius ciklines sporto šakas ir sportinius žaidimus. Vertinome kūno masès komponentus (KMK), centrinès nervu sistemos (CNS), raumenu bei širdies ir kraujagysliu sistemos (ŠKS) funkciniu rodikliu kaitos ypatybes. Tyrimo metu taikyti šie metodai: kūno masès komponentu nustatymas, tepingo testas, Rufjè fizinio krūvio mèginys, vertikalaus šuolio testas, 30 s vertikalaus šuoliavimo testas, arterinio kraujospūdžio matavimas, elektrokardiografija, dinamometrija.

Tyrimai tarp grupiu neatskleidè didelio cikliniu sporto šaku ir sportiniužaidimu pratybu poveikio 11-14 m. berniuku CNS darbingumo ir funkcinès būklès rodikliams. Stebint motorinès sistemos rezultatus nustatyta, kad visu amžiaus grupiu sportuojančiuju rezultatai buvo geresni už nesportuojančiuju: $13 \mathrm{~m}$. grupejje geriausiu rezultatu pasieke žaidèjai, o 14 m. — cikliniu šaku sportininkai. Atliekant dinamometrinius matavimus nustatyta, kad cikliniu šaku sportininku raumenujëga yra didesnè už nesportuojančiuju ir žaideju. Tai rodo, kad bet kokie fiziniai krūviai (iš dalies ar griežtai reglamentuoti) teigiamai veikia sparčiai besivystantị organizma, lemia sportinius rezultatus. Vertinant širdies susitraukimu dažnio (ŠSD) reikšmes nustatyta, kad mažiausios jos buvo žaidëju, ypač 13 m. grupëje, ir reikšmingai skyrèsi nuo nesportuojančiuju ir cikliniu šaku sportininku.

Išvados: 1) fiziniu krūviu pobūdis reikšmingai veikia vaiku raumenu darbingumo rodikliu gerèjimo tempus: $11-14$ m. amžiaus tarpsniu raumenujègos rodikliai sparčiau didejo besitreniruojančiu cikliniu sporto šaku grupiu nei žaidẻju ar nesportuojančiuju; 2) reguliarūs fiziniai krūviai gerina ŠKS funkcionaluma, 13 m. amžiaus tarpsniu geresniais ŠKS funkciniais rodikliais išsiskiria žaidëjai.

Raktažodžiai: sportiniai žaidimai, cikliniai pratimai, širdies ir kraujagysliu sistema, centriné nervu sistema.

\section{IVADAS}

B iologine branda yra vienas iš reikšmingu veiksnių, lemiančių fiziologini atsaką i fizinius krūvius (Rowland, 1996). Ilgalaikio kartotinio fizinio krūvio metu kinta ŠKS (Pober et al., 2004), griaučių raumenų darbingumo rodikliai, ir šie struktūriniai bei funkciniai pokyčiai laikomi ilgalaikès adaptacijos fenomenu. Širdies funkcinès galimybès dažnai tampa organizmo adaptacinių galimybių ribojamuoju veiksniu, dẻl to ŠKS adaptacija prie fizinių krūvių yra viena iš svarbiausių sąlygu, lemiančiu bendrą organizmo adaptaciją aplinkoje. Augant organizmui, per pirmuosius 10 - 15 metu fizinio krūvio metu labiausiai kinta ŠSD (Hainsworth, 1995; Fletcher et al., 1996). 
Vaikų ir paauglių organizmo struktūros motorinių ir funkciniu ypatumų pažinimas, tarp ju ir sąsajų su kitomis organizmo struktūrinèmis dalimis, yra svarbus norint kiek galima geriau lavinti motorines funkcijas (Olson, 1996; Munchmeier, 2001). Fiziniais pratimais galima pagerinti daugeli funkcinių rodiklių, tačiau pažanga priklauso ir nuo fenotipinès adaptacijos, ir nuo taikomu pratimu pobūdžio. Laikoma, kad vaikų fizinio parengtumo kaitą labiausiai veikia sporto šakų, reikalaujančiu greitai reaguoti i naujus išorès dirgiklius, pratybos, pavyzdžiui, žaidimai, trumpujų nuotolių bègimas, fechtavimasis, boksas, imtynès ir kt. (Olson, 1996; Kozlowski et al., 2001).

Tyrimo tikslas - palyginti iš dalies reglamentuoto fizinio krūvio, būdingo sportinių žaidimų veiklai, ir griežtai reglamentuoto fizinio krūvio, vyraujančio ciklinių sporto šakų treniruotèse, poveiki vaikų funkciniam parengtumui.

\section{TYRIMO METODIKA}

Tiriamujų kontingentą sudare $25711-14 \mathrm{~m}$. amžiaus berniukai. Visi tiriamieji suskirstyti $\mathfrak{i}$ tris grupes: nesportuojantys $(11 \mathrm{~m} ., \mathrm{n}=22 ; 12 \mathrm{~m} ., \mathrm{n}=$ $18 ; 13$ m., $\mathrm{n}=25 ; 14$ m., $\mathrm{n}=20$ ), kultivuojantys ciklines sporto šakas - lengvaatlečiai bègikai (11 m., $n=22 ; 12$ m., $n=20 ; 13$ m., $n=24 ; 14$ m., $\mathrm{n}=23)$ ir žaidejai - krepšininkai, rankininkai, futbolininkai (11m., $\mathrm{n}=21 ; 12 \mathrm{~m}$., $\mathrm{n}=20 ; 13 \mathrm{~m}$., $\mathrm{n}=22 ; 14$ m., $\mathrm{n}=20$ ).

Berniukai dvi dienas prieš tyrimus neatliko varginančių fizinių krūvių. Vertinome kūno masès komponentus, CNS, raumenų ir ŠKS funkcinių rodiklių kaitos ypatybes. Kūno masès komponentai buvo vertinami bioelektrinio impedanso metodu (kūno kompozicijos analizatoriumi Tanita TBF-300). Matuoti rodikliai: kūno masès indeksas (KMI, $\left.\mathrm{kg} / \mathrm{m}^{2}\right)$, kūno masè $(\mathrm{kg})$, riebalinio audinio kiekis (\%), aktyvioji kūno masè $(\mathrm{kg})$, bendroji kūno vandens mase $(\mathrm{kg})$. CNS funkcijai vertinti buvo naudojamas $40 \mathrm{~s}$ trukmès tepingo testas, atliekamas spaudžiant pasirinktą kompiuterio klaviatūros klavišą. Kompiuterinè programa ivertindavo ir pateikdavo normalizuotas registruojamų rodiklių reikšmes - CNS darbingumo ir funkcinès būklès rodiklius (CNS paslankumą ir nuovargi, asimetriškumą, bendraji CNS darbingumą, anaerobini darbingumą ir anaerobinio darbingumo talpą) pagal Ukrainos mokslininku (Зеленцов, Лобановский, 1998) metodiką. Raumenų darbingumas buvo vertinamas pagal dinamometrijos ir vertikalaus šuolio iš vietos bei
$30 \mathrm{~s}$ trukmès šuolių serijos rezultatus. Vertikalaus šuolio aukščiui matuoti buvo naudota kontaktine platforma „Kistler“ (BioWare Performance Software Version 3.0) ir su ja sujungtas kompiuteris, kuriame irengta programa, apskaičiuojanti vertikalaus šuolio aukštị. Dinamometru „Nicholas“ matuota: rankos keliamujų, šlaunies lenkiamujų, blauzdos tiesiamuju, blauzdos lenkiamuju, dilbio lenkiamujų ir dilbio tiesiamujų raumenu jèga. Prietaisas dedamas tarp tyrejjo rankos ir norimos išmatuoti tiriamojo galūnès. Tyrèjo spaudimo jèga per dinamometrą nukreipta i matuojamą galūnę (Bačiulienè, 2006).

ŠKS funkcija buvo vertinama registruojant EKG ir matuojant arterinio kraujo spaudimo (AKS) rodiklius Rufjè fizinio krūvio mėginio bei 30 s trukmès vertikalių šuolių metu. Kauno medicinos universiteto Kardiologijos institute sukurta kompiuterinè EKG analizès sistema „Kaunaskrūvis" apskaičiuodavo ir pateikdavo ŠKS funkciniu rodiklių visų 12 EKG atvadų vidurkiu (per $10 \mathrm{~s})$ registruojamų rodiklių reikšmes, jų pokyčius. Buvo vertinami šie rodikliai: širdies susitraukimu dažnis, JT intervalas, JT / RR intervalų santykis, ST segmento depresija.

Vertinant gautus tyrimo rezultatus, visais atvejais buvo nustatomas aritmetinis vidurkis $(\bar{x})$ ir standartinis nuokrypis $(S)$. Tyrimo metu nustatant skirtumo patikimumą tarp rodiklių vidurkiu buvo naudojamas Stjudento t (Student $t$ ) kriterijus, taikomas nepriklausomoms imtims. Patikimas skirtumas tarp lyginamujų dydžių laikytas tada, kai paklaida neviršydavo $5 \%$, t. y. p $<0,05$.

\section{REZULTATAI}

Didžiausi kūno masès indekso rodikliai $14 \mathrm{~m}$. berniukų. Jie statistiškai patikimai skyrèsi tarp nesportuojančių berniukų ir ciklinių šakų sportininkų bei žaidejjų. 12 ir $13 \mathrm{~m}$. tiriamuju grupèse pratybos beveik neveikè kūno masès indekso rodiklių. Sportuojančiujų grupėse riebalinio audinio kiekis $11-14 \mathrm{~m}$. amžiaus tarpsniu mažèjo (1 pav.). Nesportuojančiuju grupejje jis mažejo tik iki $13 \mathrm{~m}$., o $14 \mathrm{~m}$. berniukų buvo didžiausias iš visu grupių ir statistiškai patikimai skyrèsi nuo žaidejjų bei ciklinių šaku sportininkų. Aktyviosios kūno masès duomenys tarp nesportuojančiu berniukų ir ciklinių šakų sportininkų bei žaidejjų statistiškai patikimai nesiskyrè. Tokia pati tendencija pastebèta atliekant bendrosios kūno vandens masès matavimus. 


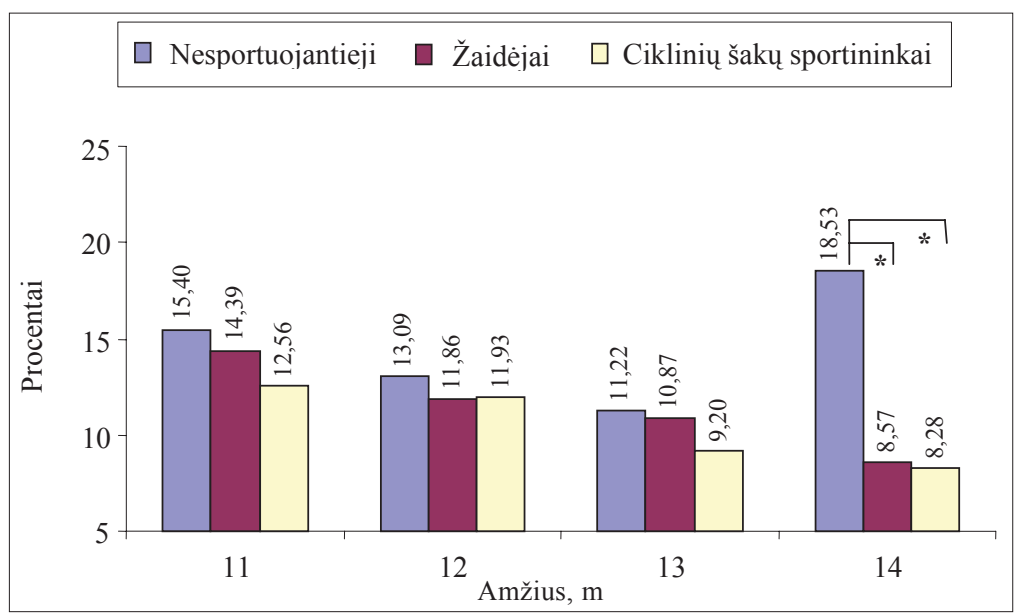

Nesportuojantieji $\quad$ Žaidèjai $\square$ Ciklinių šakų sportininkai
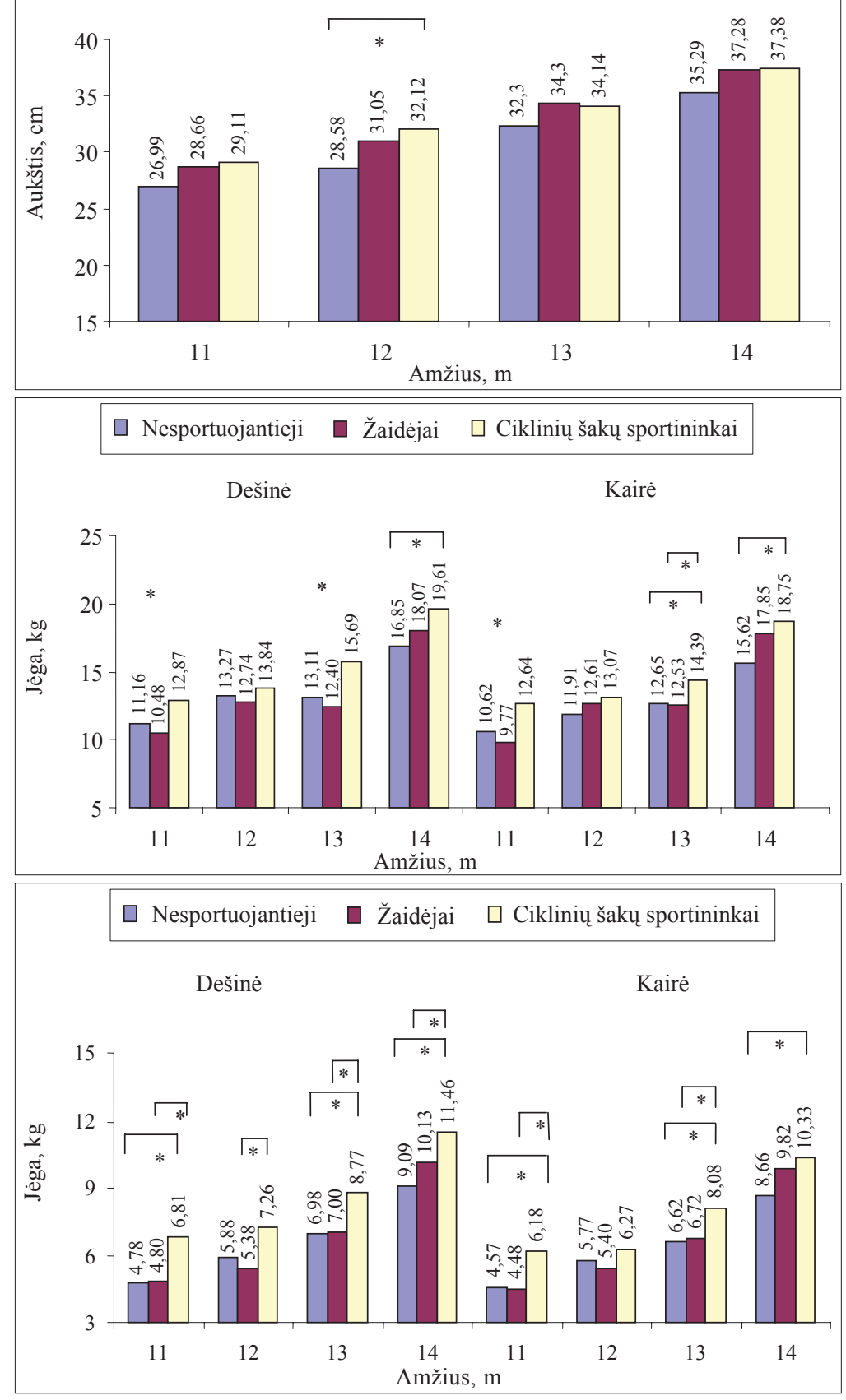

1 pav. Nesportuojančių berniukų, žaidèjų ir ciklinių šaku sportininkų riebalinio audinio kiekio rodikliai

Pastaba. * - statistiškai patikimas skirtumas, $\mathrm{p}<0,05$.

2 pav. Nesportuojančių berniukų, žaidèjų ir ciklinių šakų sportininkų maksimalaus šuolio aukščio rezultatai

Pastaba. * - statistiškai patikimas skirtumas, $\mathrm{p}<0,05$.

3 pav. Nesportuojančių berniukų, žaidèjų ir ciklinių šakų sportininkų šlaunies lenkiamųjų raumenų jẻgos rodikliai

Pastaba. * - statistiškai patikimas skirtumas, $\mathrm{p}<0,05$.

4 pav. Nesportuojančių berniukų, žaidėjų ir ciklinių šakų sportininkų dilbio tiesiamųjų raumenų jègos rodikliai

Pastaba. * - statistiškai patikimas skirtumas, $\mathrm{p}<0,05$. 
5 pav. Nesportuojančių berniukų, žaidèjų ir ciklinių šakų sportininkų ŠSD kaita Rufjè mèginio ir $30 \mathrm{~s}$ vertikalaus šuoliavimo metu
Pastaba. Rodikliu skirtumas tarp nesportuojančiuju ir žaidejju — a, nesportuojančiujų ir ciklinių šakų sportininkų — b, žaidejju ir ciklinių šaku sportininku - c (statistiškai patikimas skirtumas, $\mathrm{p}<0,05$ ).

1 EKG - prieš krūvị; 4-14 EKG - atsigavimas po Rufjè mėginio; 15 - 25 EKG - atsigavimas po $30 \mathrm{~s}$ vertikalaus šuoliavimo testo.

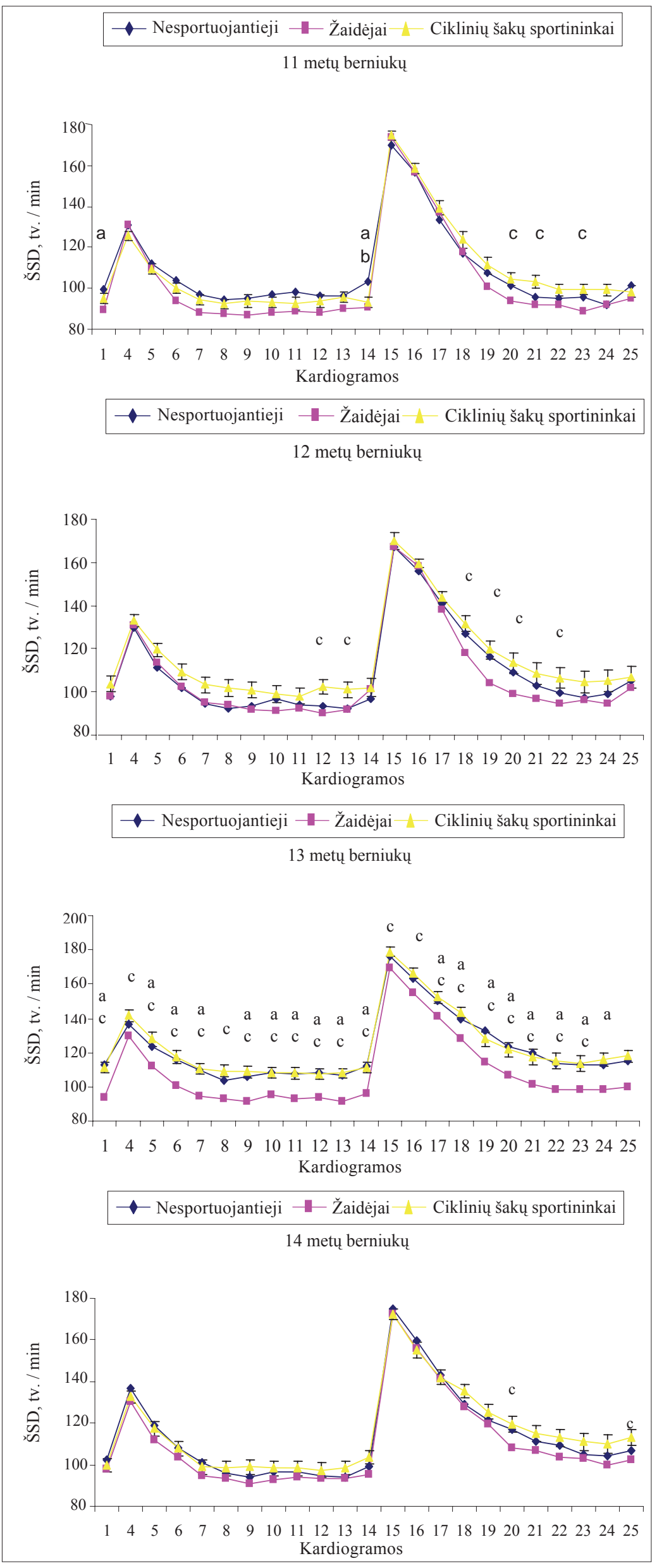


Atliekant tepingo testą, visų amžiaus grupių piršto judesių dažnio suma per $40 \mathrm{~s}$ statistiškai reikšmingai nesiskyrè. Maksimalus trylikamečiu rankos judesių dažnis buvo ciklinių šakų sportininkų ir statistiškai patikimai skyrèsi nuo žaidejų $\mathrm{Ne}$ sportuojančių berniukų ir asmenų, kultivuojančių ciklines sporto šakas bei sportinius žaidimus, CNS asimetrija skiriasi netolygiai, todèl statistiškai patikimai nesiskiria kaip ir CNS paslankumas. CNS nuovargio rodikliai didžiausi buvo nesportuojančiu berniukų, bet statistiškai patikimai skyrèsi nuo ciklinių šakų sportininkų ir $13 \mathrm{~m}$. žaidèjų grupejje. Bendrojo CNS darbingumo, anaerobinio darbingumo bei anaerobinio darbo talpos rodikliu skirtingo pobūdžio pratybos neveikè ir statistiškai reikšmingo rodiklių skirtumo neaptikta.

Maksimalaus šuolio aukščio rezultatai geresni buvo sportuojančiu $11-14 \mathrm{~m}$. berniukų nei nesportuojančiujuc, tačiau statistiškai patikimas skirtumas buvo nustatytas tik nesportuojančiu berniuku ir $12 \mathrm{~m}$. ciklinių šakų sportininkų grupėse (2 pav.).

$30 \mathrm{~s}$ vertikalaus šuoliavimo testo rezultatai parode, kad nesportuojančiu berniukų šuolio aukštis ir galingumas buvo mažesnis nei cikliniu šakų sportininkų ir žaidejjų — rodikliai statistiškai patikimai skyrèsi testo pradžioje. Lyginant visu keturių amžiaus grupių $(11,12,13,14 \mathrm{~m}$.) dinamometrinius rodiklius, t. y. visų pasirinktų raumenų grupių (rankos keliamuju, šlaunies lenkiamujų ( 3 pav.), blauzdos tiesiamujų ir lenkiamuju, dilbio lenkiamujų ir tiesiamuju raumenų (4 pav.)) išmatavimus nustatyta, kad geriausiu rezultatu pasiekė ciklinių šakų sportininkai. Prasčiausi rezultatai nesportuojančių berniukų. Vertinant dinamometrinius rodiklius, daugiausia statistiškai patikimu skirtumų aptikta ne tik lyginant cikliniu šakų tiriamuosius su nesportuojančiaisiais, bet ir su žaidejais.

Sistolinis kraujospūdis (SAKS) $11 \mathrm{~m}$. tiriamuju grupejje prieš Rufjè mėgini ir po jo didžiausias buvo nesportuojančiu berniukų ir statistiškai patikimai skyrèsi nuo cikliniu šakų sportininku ir žaidejju rodiklių. Tiriamiesiems atlikus $30 \mathrm{~s}$ vertikalaus šuoliavimo testa, reikšmingo rodikliu skirtumo neaptikta. Panašūs rodikliai nustatyti ir stebint diastolini kraujospūdi (DAKS), tik nesportuojančiu berniuku jis buvo žemiausias. 12 ir $13 \mathrm{~m}$. grupiu SAKS viso tyrimo metu statistiškai patikimai nesiskyrè, o DAKS rodikliai, atlikus $30 \mathrm{~s}$ vertikalaus šuoliavimo testa, patikimai skyrèsi tarp žaidèjų ir nesportuojančiujų. Sporto šakos pratybos neturèjo poveikio $14 \mathrm{~m}$. berniuku SAKS ir DAKS rodikliams.
Visų amžiaus grupių žaidèjų ŠSD buvo žemiausias (5 pav.). 11 ir $14 \mathrm{~m}$. amžiaus tarpsniu beveik nèra statistiškai patikimo šio rodiklio skirtumo tarp nesportuojančiujų ir sportininkų. $12 \mathrm{~m}$. amžiaus tarpsniu atsigavimo pabaigoje po Rufjè mèginio ir beveik viso atsigavimo metu po $30 \mathrm{~s}$ vertikalaus šuoliavimo testo statistiškai patikimas rodikliu skirtumas nustatytas tarp ciklinių šakų sportininkų ir žaidèjų. Tirtų $13 \mathrm{~m}$. nesportuojančių berniukų ir ciklinių šakų sportininku ŠSD rodikliai beveik vienodi. Šie rodikliai viso tyrimo metu statistiškai patikimai skyrèsi nuo žaidèjų.

Vertinant JT intervalo kaitą nustatyta, kad nèra statistiškai patikimo skirtumo tarp nesportuojančių berniuku ir sportininkų rodikliu 11, 12 ir $14 \mathrm{~m}$. amžiaus tarpsniu. Kitokia padètis tiriant $13 \mathrm{~m}$. berniukus. Čia JT intervalas yra didžiausias žaidejju ir viso tyrimo metu statistiškai patikimai skyrèsi nuo nesportuojančiujų ir ciklinių šakų sportininku.

\section{REZULTATŲ APTARIMAS}

Jauno sportininko organizmas skiriasi nuo suaugusiojo. Paauglys gerai adaptuojasi prie suaugusių sportininkų treniruotès režimo, tačiau vaiku ir paaugliu parengiamosios programos turi būti sudaromos kiekvienai amžiaus grupei individualiai, atsižvelgiant $\mathfrak{i}$ visus fizinès brandos veiksnius (Malina, Bouchard, 1991; Philippaerts et al., 2006). 11-14 m. amžiaus tarpsniu organizmas labai jautrus išorès poveikiams, todèl sportuojančių šio amžiaus berniukų tyrimai yra reikalingi ir gali atskleisti sudetinga igimtu ir igyjamu (endogeniniu ir egzogeninių) veiksnių ryší. Tokio pobūdžio žinios yra reikalingos sporto specialistams, norint optimaliau suplanuoti fizinio krūvio paveikumą.

Kūno masès komponentų tyrimas parodè, kad KMI didžiausias buvo $14 \mathrm{~m}$. nesportuojančių berniukų ir statistiškai patikimai skyrèsi nuo sportuojančiujų. Taip pat grupių tyrimas atskleide stiprų fiziniu pratimu poveiki riebalinio audinio kiekiui $14 \mathrm{~m}$. amžiaus tarpsniu - nustatytas statistiškai reikšmingas skirtumas tarp nesportuojančiu ir sportuojančių berniukų. Tai rodo, kad bet kokie fiziniai krūviai (iš dalies ir griežtai reglamentuoti) teigiamai veikia sparčiai besivystanti organizmą, lemia sportinius rezultatus (Spirduso, 1995; Sadzevičienè, 2005).

Atliekant tepingo testą bandyta nustatyti skirtingo kryptingumo fizinių krūvių poveiki CNS 
funkciniam parengtumui. Deja, tyrimai tarp grupiu neatskleidè didelio ciklinių šakų ir sportinių žaidimu pratybų poveikio $11-14 \mathrm{~m}$. berniuku CNS darbingumo ir funkcinès būklès rodikliams. Tik CNS vnuovargis statistiškai patikimai buvo didesnis nesportuojančių berniukų nei ciklinių šaku sportininkų.

Šuolio aukštis priklauso nuo raumenu susitraukimo veiksmingumo, o pastarasis ne tik nuo biocheminių veiksnių (Malina, Bouchard, 1991), bet ir nuo pratybų krūvio (Mamkus, 1998; Stanislovaitis, 1998). Vertinant $11-14 \mathrm{~m}$. berniuku motorinès sistemos funkcinio parengtumo rodiklius nustatyta, kad maksimalus šuolio aukštis sportuojančių berniukų buvo didesnis už nesportuojančiujuc, nors statistiškai reikšmingas skirtumas aptiktas tik $12 \mathrm{~m}$. grupeje tarp nesportuojančių berniuku ir ciklinių šakų sportininkų. Kitas tyrimo metu taikytas testas motorinei sistemai ivertinti -30 s vertikalus šuoliavimas. Čia visu amžiaus grupių sportuojančiujų rezultatai buvo geresni už nesportuojančiujų. Statistiškai patikimai skyrèsi nesportuojančių berniukų ir cikliniu šakų sportininkų bei 11 ir $12 \mathrm{~m}$. žaidèjų rezultatai tik testo pradžioje. $13 \mathrm{~m}$. grupejje geriausių rezultatų pasiekè žaidèjai, o $14 \mathrm{~m}$. - ciklinių šaku sportininkai. Tai patvirtina kitų autorių organizmo adaptacijos prie fizinių krūvių dèsningumu tyrimo duomenis (Balsom et al., 1992; Rudas ir kt., 2006). Atlikti dinamometriniai matavimai parode, kad ciklinių šaku sportininkų raumenu funkcinio parengtumo rodinkliai yra geresni už nesportuojančių berniukų ir žaidejų. Statistiškai patikimi rodiklių skirtumai buvo nustatyti visose amžiaus grupèse vertinant berniukų kūno dešinę ir kaire puses. Raumenu darbingumo vertinimo duomenys patvirtino ir daugelio kitu autoriu teiginius, kad fiziniai pratimai veikia augimo ir vystymosi procesus (Rowell, 1997; Wilmore, Costill, 1999).

Vertinant ŠSD rodiklius nustatyta, kad mažiausios ŠSD reikšmès žaidejju grupėje. Jos statistiškai patikimos buvo tik po anaerobinio krūvio (30 s vertikalaus šuoliavimo testo). Lyginant gautus duomenis nustatyta, kad mažiausi ŠSD rodikliai $13 \mathrm{~m}$. žaideju grupejje ir jie reikšmingai skyrèsi nuo nesportuojančiuju bei cikliniu šakų sportininkų. Taigi mažesni ŠSD rodikliai rodo, kad sportinių žaidimų pratybas lankančių berniuku širdies susitraukimai lètesni - ilgesnè diastole (širdies atsipalaidavimas), greitesne ŠKS mobilizacija krūvio pradžioje. Visgi kiek lèčiau šios žaidèjų funkcijos atsigauna po fizinių krūvių nei ciklinių šakų sportininkų. Tai liudija, kad fizinių krūvių specifiškumas veikia ŠKS adaptacijos ypatybes.

Elektrokardiogramos JT intervalas gali būti laikomas skilvelių repoliarizacijos trukmès rodikliu (Hlaing et al., 2005), o jo kaita glaudžiai susijusi su miokardo metabolizmo kaita (Vainoras, 2002). 11, 12 ir 14 m. skirtingu sporto šaku berniukų JT intervalo kaita buvo analogiška ir statistiškai patikimo skirtumo tarp grupių rodiklių nenustatyta. Todèl galima teigti, kad fiziniai krūviai negreitai paveikia miokardo metabolizmo ypatumus ir pasireiškia per trumpą treniravimosi laikotarpi. Tačiau $13 \mathrm{~m}$. amžiaus grupès tiriamujų elektrokardiogramos JT intervalo reikšmès statistiškai patikimai skyrèsi žaidejjų nuo ciklinių šakų sportininkų ir nesportuojančių tiriamujų. Vadinasi, reguliarūs fiziniai krūviai gerina ŠKS funkcionalumą. Tyrimo rezultatai patrodè, kad $13 \mathrm{~m}$. amžiaus tarpsniu žaidejjų ŠKS funkciniai rodikliai geresni už nesportuojančiujuc ir net lankančiujų ciklinių sporto šakų pratybas.

\section{IŠVADOS}

1. Fizinių krūvių pobūdis reikšmingai veikia vaikų raumenų darbingumo rodiklių gerejjimo tempus. 11-14 m. amžiaus tarpsniu raumenu jègos rodikliai sparčiau didejjo ciklinių sporto šakų tiriamuju grupėse nei žaidèjų ar nesportuojančiujų.

2. Reguliarūs fiziniai krūviai gerina ŠKS funkcionaluma, $13 \mathrm{~m}$. amžiaus tarpsniu geresniais ŠKS funkciniais rodikliais išsiskiria žaidejjai. 


\title{
LITERATŪRA
}

Bačiulienè, K. (2006). Vaiku laikysenos rodikliu, širdies ir kraujagysliu sistemos bei jégos parametru sqsaju vertinimas: daktaro disertacija. Kaunas: KMU.

Balsom, P. D., Seger, J. Y., Sjodin, B., Ekblom, B. (1992). Physiological responses to maximal intensity intermittent exercise. European Journal of Applied Physiology, 65, $144-149$.

Fletcher, G. F., Balady, G., Blair, S. N. (1996). Recommendations for physical activity programs for all Americans: A statement for health professionals by the Committee on Exercise and Cardiac Rehabilitation of the Council on Clinical Cardiology. American Heart Association: Circulation, 94, 857-862.

Hainsworth, R. (1995). The control and physiological importance of heart rate. Heart Rate Variability, 3-19.

Hlaing, T., Dimino, T., Kowey, P. R., Yan, G. X. (2005). ECG Repolarization Waves: Their Genesis and Clinical Implications. Annals of Noninvasive Electrocardiology, 10 (2), 211-223.

Kozlowski, S. W., Gully, S. M., Brown, K. G. et al. (2001). Effects of Training Goals and Goal Orientation Traits on Multidimensional Training Outcomes and Performance Adaptability. Organizational Behavior and Human Decision Processes, 85 (1), 1-31.

Malina, R. M., Bouchard, C. (1991). Growth, Maturation and physical activity. Human Kinetics, 33, 57-59.

Mamkus, G. (1998). Amžiaus ir treniruorès poveikis koju raumenu susitraukimo ir atsipalaidavimo savybems: disertacijos santrauka. Kaunas: LKKA.

Munchmeier, R. (2001). Growing up in changing conditions on the structural change of childhood and adolescence. Prax Kinderpsychol Kinderpsychiatr, 50 (2), 119-134.

Olson, D. (1996). What is training? Current Biology, 6 (12), 1539

Philippaerts, R. M., Vaeyens, R., Janssens, M. et al. (2006).
The relationship between peak height velocity and physical performance in youth soccer players. Journal of Sports Science, 24 (3), 221.

Pober, D. M., Braun, B., Freedson, P. S. (2004). Effects of a single bout of exercise on resting heart rate variability. Medicine and Science in Sports and Exercise, 36 (7), $1140-1148$

Rowell, L. B. (1997). Neural control of muscle blood flow: Importance during dynamic exercise. Clinical Experiment Pharmacological Physiology, 24, 117-125.

Rowland, T. H. (1996). Developmental exercise physiology. Human Kinetics, 14-25.

Rudas, E., Skurvydas, A., Mickevičienè, D., Bulotienè, D. (2006). Mergaičiu ir berniukų šoklumo kaita. Ugdymas. Küno kultūra. Sportas, 1 (60), 56-62.

Sadzevičienè, R. (2005). Asmenu, adaptuotu greitumo jégos fiziniams krūviams, funkcinès būklès ypatybès ir kaita mezociklo pratybose taikant koncentruotus aerobinius ir anaerobinius krūvius: daktaro disertacija. Kaunas: LKKA.

Spirduso, W. W. (1995). Physical dimensions of ageing. Human Kinetics, 37-41.

Stanislovaitis, A. (1998). Influence of specialized strength, sprint and endurance training loads on adaptation characteristics of the function of human skeletal muscules: Summary of doctoral dissertation. Kaunas: LKKA.

Vainoras, A. (2002). Functional model of human organism reaction to load - evaluation of sportsman training effect. Ugdymas. Küno kultūra. Sportas, 3, 88-93.

Wilmore, J. H., Costill, D. L. (1999). Physiology of exercise and sport. Champaign. P. 549.

Зеленцов, А. М., Лобановский, В. В. (1998). Моделирование тренировки в футболе. Киев. С. 1217.

\section{IMPACT OF SPORTS GAMES AND CYCLIC SPORTS EVENTS ON 11-14 YEAR-OLD BOYS' FUNCTIONAL PREPAREDNESS}

\author{
Arūnas Emeljanovas, Jonas Poderys \\ Lithuanian Academy of Physical Education, Kaunas, Lithuania
}

\begin{abstract}
The age of 11 to 14 years is very sensitive to external influences, therefore we need deeper understanding of adaptational effects at this age as it can reveal complex interaction between internal and external (endogenous and exogenous) influences. The aim of this study was to compare the effects of physical loads of variable intensity (sports games) and cyclic nature on the changes of body functioning. The participants of the study were 257 boys aged $11-14$ years. All the participants were divided into three groups: non-athletes, engaged in cyclic sports events - track and field athletes and engaged in sports games athletes — basketball, volleyball, football players. The dynamics of body mass components, indices of cardiovascular and central nervous systems (CNS) and muscle performance indices were analyzed as well.

Longitudinal and crossectional assessments did not reveal a significant impact of cyclic sports events and sports games on the indices of CNS of 11-14 years-old boys. While observed indices of motor system
\end{abstract}


performance abilities in all ages in athletes cohorts were higher than those in non-athletes cohort: the best results were demonstrated by the participants of sports games groups aged 13 years, and in the group of boys aged 14 years the best results were produced by athletes of cyclic sports events.

Dynamometric measurements revealed that the highest muscle power indices were reached by the participants of cyclic sports events in comparison with non-athletes and the cohort of sports games. The results obtained during the study indicated that any type of physical load (partially regulated or strictly regulated) had influence on the constitution of rapidly developing bodies and had positive impact on the growth and the development, as well as sports results. Estimation of heart rate (HR) values revealed that HR indices of children attending sports games training sessions were significantly lower than of non-athletes and cyclic sports events athlete cohorts, especially aged 13 years.

Conclusions: 1. The improvement muscle performance indices depends on the type of physical load: the increase of muscle of the boys aged 11-14 years in cyclic sports cohort was higher than of those in sports games and non-athletes. 2. Regular training improves cardiovascular adaptation but sports games training sessions have the highest impact for the boys aged 13 years.

Keywords: sports games, cyclic sports events, cardiovascular system, central nervous system.

Gauta 2008 m. gegužės 1 d.

Received on May 1, 2008

Priimta 2008 m. gruodžio 9 d.

Accepted on December 9, 2008

\author{
Arūnas Emeljanovas \\ Lietuvos kūno kultūros akademija \\ (Lithuanian Academy of Physical Education) \\ Sporto g. 6, LT-44221 Kaunas \\ Lietuva (Lithuania) \\ Tel +370 37302669 \\ E-mail a.emeljanovas@1kka.lt
}

